\title{
Generating hope in pastoral care through relationships
}

\author{
Authors: \\ Tobias H. Steyn ${ }^{1}$ \\ Maake J. Masango ${ }^{1}$ \\ Affiliations: \\ ${ }^{1}$ Department of Practical \\ Theology, University of \\ Pretoria, South Africa \\ Note: \\ This article is an adaptation \\ of Tobias Steyn's PhD \\ dissertation, undertaken \\ within the Department of \\ Practical Theology at the \\ University of Pretoria, as \\ supervised by Prof. Maake \\ Masango. \\ Correspondence to: \\ Maake Masango \\ Email: \\ maake.masango@up.ac.za \\ Postal address: \\ PO Box 84173, Greenside \\ 2034, South Africa

\section{Dates:} \\ Received: 09 Sept. 2010 \\ Accepted: 14 Sept. 2011 \\ Published: 07 May 2012 \\ How to cite this article: \\ Steyn, T.H. \& Masango, M.J., \\ 2012, 'Generating hope \\ in pastoral care through \\ relationships', HTS Teologiese \\ Studies/Theological Studies \\ 68(1), Art. \#957, 7 pages. \\ http://dx.doi.org/10.4102/ \\ hts.v68i1.957
}

C 2012. The Authors. Licensee: AOSIS OpenJournals. This work is licensed under the Creative Commons Attribution License.
This article concerned itself with the notion of Christian hope, in the midst of suffering, where this hope will find its energy from within a relationship with God and his people. Hope in God finds its substance from our past, our present and our future relationship with God. Because of this relationship, Christian hope urges caregivers and care seekers into action, enabling them to resist evil and bringing liberation in suffering.

\section{Introduction}

In his book, entitled Pastoral care in context, Patton (1993) sketched a scene where the shepherd is caring for the whole flock, and not so much for the needs of the individual, because it is through tending the whole flock, that the caregiver meets the individual's need. The reader needs to be mindful of the context in which Patton is writing, because, from Patton, we realise that the shepherd never loses his compassion for the individual within the flock. At this point, Patton (1993) becomes even more challenging when he quantifies the measure of peoples' humanity by their ability, or their willingness, to care for one another:

Care is what makes the human being human. If we do not care, we lose our humanity ... Heidegger is helpful in reminding the pastoral carer that care is more than what we feel, think, or do ... It is what we in fact are - caring. (p. 17)

From the above, we are confronted with the idea that our care should be for the flock, as well as for the individual within the flock. Because our humanity depends on our care for both the flock and the individual, we need to consider the whole life of this flock or person; that is, their past, present and future. We, ourselves, live in close relationship with those to whom we seek to offer care in this life. Thus, in this context, pastoral ministry becomes a ministry of hope, built upon our positive way of relating to people, even those who persecute us.

\section{Who will care pastorally for those in need?}

Pastoral care often happens through the care seekers' community, because 'our individual wellbeing is inextricably linked to the well-being of the larger whole' (ed. De Beer 2002:32). Because they belong to a larger community, the individual care seeker finds meaning in life. This explains why people who do not belong to a larger community often experience separation and despair, as Patton (1993:26) continues: 'The issue of being forgotten is not just a concern of Israel. It is a genuine pastoral issue.' Patton (1993:15) based his understanding of pastoral care on his theological conviction that humans are able to care in a pastoral way, 'because we are held in God's memory.' Scripture forcefully reinforces this notion when the prophet wrote: 'Can a mother forget the baby at her breast and have no compassion on the child she has borne? Though she may forget, I will not forget you' (Is 49:15).

Because God has not forgotten his people, they are able to remember the people around them. As people live through negative experiences, they may think that God has forgotten them, but, to the contrary, God lives the Christians' life experiences within them. He is Immanuel, 'God with us.' However, this notion introduces a great paradox, because caregivers need to be mindful that God is with his people and within his people; yet, God is also with those considered not to be his people, whether they believe and accept God as their father or not.

Jackson (1985:129) argued that the source and motive for our pastoral care 'is to be found in the pastor's own personal experiences of the gospel and in the actual exercise of the pastor's own pastoral gifts'. As authors and practical theologians, we wish to add to this by saying that pastoral care goes deeper than mere actions and pastoral gifts. It is so much more than what we do; in short, it becomes the very person we are. This becomes evident when we meet people in despair and we have no idea how to help them. At times such as these, we often tend to become very aware of our own personal shortcomings and lack of wisdom and skill. However, the sense of 
community created through sharing in human presence, as we spend time with these people, often creates a place where pastoral care can occur more easily. Could it be because God, who lives within the believer, came to care for people in need? Would it be too presumptuous to say that Christian human presence represents God's presence because he is Emmanuel? As children of God, we become people of authority (1 Jn 3:1). Moreover, it is from this position of Godgiven authority that we can now care for the uncared, that we can love the unloved, that we can bring hope to the hopeless and, in so doing, relate differently to people. This can occur only because God lives within his people.

\section{Pastoral care brings hope}

Christians find confidence in the care they offer because they claim to be people hoping in God. Their faith in God becomes an unwavering hope and trust in that which is not yet, but which is sure to come (Heb 11). The Apostle Paul also notices this theme by saying:

... hope that is seen is no hope at all. Who hope for what he already has? However, if we hope for what we do not yet have, we wait for it patiently. ( $R m$ 8:24-25)

Hope is in the unseen; a trust in the things still to come. However, Crabb (1988) argues that it has become very difficult to embrace the idea of hope and trust, whilst suffering is a mystery and beyond human comprehension:

There is something terribly attractive about knowing what to do to make things better. If we can explain why we feel so bad in terms of something specific and correctable, then we can do something about it. Moreover, we like that. Nothing is more terrifying than starting at a problem for which we have no solutions under our direct control. Trusting another is perhaps the most difficult requirement of the Christian life. We hate to be dependant because we have learned to trust no one, not fully. We know better. Everyone in whom we have placed our confidence has in some way disappointed at the end of relationship. To trust fully, we conclude, is suicide. (p. 15)

The truth of this situation is surprising, because it is the understanding that God cares about his creation and that he is mindful of people (Ps 8:4), which strengthens faith and quickens hope within the believer. If God truly cares about people, and people consider this true, hope lives within these believing people. However, this hope will not free the believer from suffering, even suffering at the hands of human beings.

Because God really cares for people, care originates from God himself and will find its praxis through human beings. From this notion, the reader can understand that this kind of hope is not possible, unless the one that hopes does so through faith in God. The author of the Book of Hebrews unmistakably connects belief and hope in such way that theologians agree that these are 'inseparable' (ed. Fitzgerald 1979:125). Crabb (1988:16) urges his reader to understand that hope cannot exist unless it is founded upon faith in Christ, because 'relief' may tarry and the believer needs to stand in faith, or they will not stand at all (see Is 7:9). In addition, Moltmann (1965) also becomes helpful when he explains his understanding of this notion:

Hope is nothing else than the expectation of those things which faith has believed to have been truly promised by God. Thus, faith believes God to be true, hope awaits the time when this truth shall be manifested; faith believes that he is our Father, hope anticipates that he will show himself to be a Father toward us; faith believes eternal life has been given us, hope anticipates it will sometime be revealed; faith is the foundation upon which hope rests, hope nourishes and sustains faith. (p. 6)

From Moltmann, we can appreciate the notion that in Christianity, hope finds its energy from within a faith in God. Hence, without faith in God, hope in God becomes impossible, because the objects of Christian hope are: eternal life (Tt 1:2), salvation (1 Th 5:8), righteousness (Gal 5:5), the glory of God ( $\operatorname{Rm~5:2),~the~appearance~of~Christ~(Tt~2:13)~and~}$ his resurrection from death (Ac 23:6). The fountainhead of Christian hope is in the death, burial and resurrection of Christ Jesus (1 Pt 1:3) because, 'Christ in you [is] the hope of glory' (Col 1:27). It is this hope that sprung from Christ living within the Christian, which will motivate the Christian to purify himself or herself, because he or she is pure already (1 Jn 3:3). We realise that no human being can claim purity because he or she is without sin, but purity comes through Christ's redemption upon the cross. Believers in Christ can claim purity only through faith and that will quicken hope within the believer.

From the above, one can say the Church becomes a people of hope. Furthermore, these people not only have hope in Christ, but they bring this hope to the hopeless people in times of suffering and despair, because, in a biblical context, hope stands for both the act of hoping and the thing for which Christians hope. This hope does not arise from the individual's desires or wishes, but comes from God. It is God himself, then, who becomes the believer's hope.

Thatcher (1974:245) reinforces this notion: 'The strong hope, which the Christian gospel imparts, is measured by the strength of the Church's hopeful response, co-operating with the risen Christ to bring about the "new creation".'

God-given hope is not wish-filled thinking, because, 'no one has yet been satisfied by mere wishing' (Bloch 1986:1354). Hope is a firm assurance about things that are unseen, about that which is still in the making, or that which in the near, or even far, future (see Rm 8:24-25).

Through practical experience, we have learned that hope in Christ has great value and comfort for those who are dying. However, we are deeply persuaded that true hope in Christ will also bring great comfort to those still alive. In times of difficulty hope will become the motivation to continue with this life, even to those in the midst of great suffering. Conradie (2005) explains this as follows:

... Christian hope is not so much that which is finite will be absorbed into the finite. The temptation is to think that the world will become eternal if it can find the space within God, if God 
is the dwelling place of the world. Instead, the Christian hope may be that God in God's infinite love will find a dwelling place amongst that which is finite. (p. 47)

Conradie professes that hope in God will benefit the believer in this life upon earth. Within the believer, hope quickens the understanding that life in Christ will never end. Hence, this union with Christ will continue both in this life on earth and thereafter. Furthermore, hope also quickens in the believer the understanding that God is concerned for his people, right here, right now and forever more, because God dwells both with and within his people. Moltmann (1965:2) urges the reader to understand that through the hope Christians possess, 'eschatology should not be its end, but its beginning'. The Apostle Paul strengthens this notion when he challenges the finality of death upon earth (1 Cor 15:54-55). Through Christ's resurrection, death has lost its victory over life, because the believer's hope will carry him or her into the eternal presence of God. Indeed, we can only echo Thatcher (1974:250) when he says, 'The time for dreaming about and envisioning God's future for the world is now.'

\section{Hope in Christ urges action in times of suffering}

Hope finds in Christ not only a consolation in suffering, but also the protest against suffering. If Paul calls death the 'last enemy' (1 Cor 15.26), then the opposite is also true: that the risen Christ, and with him the resurrection hope, must be declared to be the enemy of death and of a world that puts up with death. Faith takes up this contradiction and thus becomes a contradiction to the world of death. That is why, wherever it develops into hope, does not cause rest but unrest, not patience but impatience:

It does not calm the unquiet heart, but is itself this unquiet heart in man [sic]. Those who hope in Christ can no longer put up with reality as it is, but begin to suffer under it, to contradict it. Peace with God means conflict with the world ... (Moltmann 1965:7)

Why would hope enter into conflict with an unjust world when Christians are at peace with God? Could this suggest that because hope in God enables a close relationship with Christ, and because Christ himself confronted the greatest injustice in human history, when peace with God is in conflict with this world, the Christian cannot allow injustices to remain unchallenged? This notion of confrontation raises another great paradox for many, both those in Christ and those who do not believe in Christ. This paradox is real, because many expect Christians to shy away from conflict in its totality. Others, again, expect conflict upon a political platform, standing toe-to-toe with the unjust. One needs to ponder whether any of the above will bring the desirable result, because it is not as simply a choice between violence or non-violence. Was it not Jesus who cleansed the temple 'violently' (Lk 19:45-46)? Yet, this same Jesus offered no resistance when tried unjustly (Mt 26:53-54). Furthermore, Jesus offered very little assistance in his time of trial (Lk 23:9), pacifically opposing those who had put him through this suffering.
In opposing the option for violence, Niebuhr holds that 'Jesus taught total non-resistance' (cited in ed. Harries 1986:105). He continues to challenge the ethical division between violent and non-violent intervention and he motivates this notion from the influence this intervention has upon the different parties involved in either. According to Niebuhr, suffering caused by non-violent intervention is as immoral and wrong as suffering caused by violent intervention. For example, '... Ghandi's boycott of English cotton resulted in the under nourishment of the children of Manchester ...' (cited in ed. Harries 1986:105). Yet, if Niebuhr is right, one should therefore not stop drug smugglers from conducting their trade because their own children might go hungry.

What is more, it seems that God's very nature is to oppose all that is evil. Jesus drove demons out, healed the sick, raised the dead and, in this all, he brought light into darkness. God did not ignore evil. In the life of Jesus, God came to set the captives free (Jn 8:36) and he did so through resisting all that is evil. One then needs to ask: Could fire become the instrument to fight fire? Could one confront violence with violence? Desmond Tutu, an archbishop (emeritus) in the Anglican Church in South Africa, also pondered this issue in the South African context during the time of Apartheid:

There are some remarkable people who believe that no one is ever justified in using violence, even against the most horrendous evil. Such absolute pacifists believe that the true Gospel of the Cross effectively rules out anyone taking up the sword, however just the cause. I admire such persons deeply, but sadly, I confess that I am made of less noble stuff. (cited in ed. Villa-Vicencio 1987:72)

Could it be that Tutu professed that, when the situation calls for it, violence should meet violence? Pannenberg (1975:123) warns that this kind of 'political commitment may become a substitute for relevance to our sense of reality' and the person may be 'found lacking in Christian faith'. Could it be that 'Christian freedom fighters' placed a higher level of hope upon violence than the hope they place upon God to resolve the problem?

In writing this article, we are very aware that the world cries out for a Christian response to violence and thus this topic needs to be researched more closely. However, this article is purposed outside of this topic and so we will refrain from going into more detail on this here.

\section{Time dimensions of hope}

As human beings, our past makes us who we are, but our perception of the future determines our current behaviour. We do the things we do, motivated by our perception of what the future will hold in the context of who or what we are. However, we have learned that both memory of the past and hope for the future have the potential to rob people of the reality of the now, as lived in the present. For many, the now only becomes a time to mourn a terrible past, or, in contrast, is spent dreaming about the goodness of the days past. What is more, for others now is merely the time to arrange a better 
and brighter future. Sadly, those who find life's energy living in the past or in the future will lose their opportunities to learn more about the God of the now. They will miss what God is saying to them now, because he is Emmanuel, the ever present One, the always 'now' God.

For the Christian, hope in Christ will enable the believer to appreciate the past, as good or bad as it was, as God ordained, and live boldly in the present, because God is both with his people now and is awaiting them in an open-ended future. Unless the Christian embraces these time dimensions of hope in Christ, he or she will find it very difficult, if not impossible to live in fullness of life with Christ, which is for the good times as well as the bad times, as God intended it to be. The reader thus needs to consider that the present is trapped between the boundaries of the lived past and a future that is yet to be. Because the Christian's hope is placed upon a God, that was, that is and that is to come, this Christian hope cannot be separated from this open-ended God; open-ended to the past; open-ended to the future; open-ended in the now. By open-ended God, we mean that God is unlimited in his love and ability to do, to give, to be, free from constraint of any dimensions of time, because he is everywhere at all time, having endless opportunities and potential in the reality of God.

Yet, this notion becomes a problem for many people. The reality of suffering confronts the Christian when it contradicts this hope in a loving and caring God. This problem is not new, as the Apostle Paul warns his reader in Romans 8:2425. Only once the believer sees God's promise of deliverance from evil in the past, through the eyes of hope, will he or she be able to receive deliverance in the present, reaching out to a rich future in Christ.

\section{Christian hope in the past tense}

Our perception of self and of our future will not come into existence in a vacuum. These perceptions are rooted in our past. It is our past stories held in our memories that determine who we are. Our past, or rather our perception of our past, will also influence how we experience the present. This perception also deeply influences how we foresee the future and in which way we will participate in this future. Lester (1995) is helpful when trying to understand this notion:

This emphasis on personal history is necessary, given the fact that past stories are so foundational for our sense of self. The self comes into existence only to the extent that it can be recollected out of the past ... A self-perception does not spring out of nowhere, but has roots in a person's history. (p. 33)

Often, these negative perceptions are embedded in the negative experiences of the past and will influence largely the hope and confidence people have in God (Schaeffler 1994:30). Keith Ward (cited in ed. Harries 1986:61-62) also contributed to this understanding and he holds that Jesus is able to restore hope, even the hope that belongs to history, built from people's memory. Unless Christian hope restores history, putting meaning into both the negative and the positive experiences, caregivers merely will help people to cope with their past, not understanding that God had purposed it. Moltmann (1965:3) thus urges the understanding that, unless Christ purposed the past, the future can, and most likely will, become meaningless.

\section{Christian hope in the present tense}

We might say that the open future, like a land of unlimited possibilities as it were, entices and fascinates human beings, making them beings who are open to the world and ready for future. However, from the viewpoint of the histories of civilisation and religion, this is not true, for '... the driving power of hope not only [is grounded] in the fascination of the open future, but also mystically in the darkness of the lived moment' (ed. Bauckham 1999:79-80). From this we realise that the future cannot come into existence unless the now is. This is true because only the now exists; the past has been, the future is still to come. Once Christ's intervention in a person's history becomes a reality for the care seeker, the present becomes purposed in God. This purpose will play itself out in the future and that will bring about Christian hope. Pannenberg (1975) continues:

The biblical experience of the present, which is new at every stage in history, throws a light back unto the past, thus making man [sic] again and again mindful of the past and obliged to remember it in the new light of his present experience and make it his own. (p. 12)

In this, Pannenberg brings about an understanding that God's present intervention enlightens his intervention of the past. We believe that this is so because God is never changing. The same God, who created everything, is the same God who resides with his people and is the same God who calls the believer into an open-ended future with him (Heb 13:8). For this reason, ancient biblical narratives are able to influence the life of a modern human being, bringing insight into that person's past, present and future. Although God is ultimately in control in the past, present and future, individuals needs to know that this present tense of hope can only be lived in the now moments of life, because God's presence with us as humans can only be experienced in the now. The now becomes the place, offering great reward for those seeking healing from God (Lester 1995:18).

\section{Christian hope in the future tense}

Lester (1995:36) believes that both the past and the present play important roles, helping hope to become a reality in peoples' lives: 'We are not only a self, we are becoming a self, and we give shape to the not-yet-conscious self through the future stories we create.' Yet, in this process, future plays the most important role, as Lester (1995:15) continues: 'We will find that hope, although rooted in the past and acted out in the present, receives its energy from the future.' In studying people diagnosed with cancer, Lester found that these people were not anxious about their past or even greatly concerned about their present suffering. Their greatest apprehension, however, was what their future holds (Lester 1995:1). Unless 
the future is a place where a better life is perceived, hope will change into despair, whether this happens over a prolonged period or not (Stone 2001:260). A life-journey without a better future and a definite destiny could very easily become an endless journey with very low energy.

\section{Where can we find hope?}

The reader will appreciate that the future is not an empty space where the thinker, in the realm of hope, will venture into the fanatical whilst exploring the void. Real hope in the future is not separating the thinker from the reality of the true self as it is playing out in the present. This would create an 'abstract visualisation' (Roberts 1990:31) of a reality still to come, because it already is and has been in the past. The reader needs to understand that this hope for the better or new is already in motion; it already existed in the past, because hope is built upon an open-ended God.

Unless the care seeker grasps the truth that yesterday's future is today's present and tomorrow it will be the past, hope in the 'nearness of God' (Moltmann 1965:15) becomes unreachable. God is in the future, as much as God is in the past, just as much as God is in the present. Christians sometimes claim to be bearers of hope, living life in the future tense; and in Christ Jesus, that is what they ought to be. This Christian hope comes alive in an open-ended future within the presence God and it will manifest with joy within Christians right now (Neh 8:10). However, this is only possible, because there has never been a time when God was not with his people. With this in mind, Callahan (1983) becomes helpful in understanding the principle that even in the times of uttermost pain and difficulty, hope will overcome despair:

Hope is stronger than memory. Salvation is stronger than sin. Forgiveness is stronger than bitterness. Reconciliation is stronger than hatred. Resurrection is stronger than crucifixion. Light is stronger than darkness ... Hope is stronger than memory. (p. xx)

Hope in the knowledge that God is with his people is stronger than the memory of the pain experienced in the past and present. It is the prospect of their future that determines people's behaviour in the now. When hope is absent, people lose their purpose for life, which, in turn, will numb their zeal for life (Poser 1987:25). People without hope are people without dreams, going through the motions of life without really living its full potential, often experience feelings of failure. It is the hope for a better tomorrow that will enable people to live life today.

\section{Why is hope important for those who suffer?}

For those care seekers in despair, tomorrow will bring no better prospect than the painful now, because the situation is impossible to improve. In this context, Lester (1995:72) brings an understanding of despair as an 'ultimate or boundary situation'. This marks out the limit to which extent people are willing to live life. The line is drawn and the person in despair is not willing to cross this boundary often set by themselves. These people cannot go beyond this imaginary point in their lives because they are trapped in hopelessness. When people are hopeless and in despair they become separated from hope in God, trapped in a 'sickness of spirit' (Lester 1995:72). This separation disrupts their very being and nature and they find it almost impossible to communicate with God. Little hope exists outside a commitment towards God who has called his people into a brighter future. Could this hope in a bright future with God be the reason why Paul and Silas praised God in prison (Ac 16:25)? Surely, their current circumstances were no inspiration to praise? Many theologians profess that it was because of their praises to God that their chains loosened. This praise, however, was motivated from their future hope in God. The reader needs to realise that hope does not free the Christian from the reality of pain and suffering in this life. In this, we hope that the reader understands that hope in God has a higher purpose than merely keeping the believer from despair. It seems that Paul suggests that the Christian's love for their fellow believers was born through faith and hope in God and this hope is cultivated through that which they 'heard about in the Word of truth' (Col 1:3-6).

God called caregivers to love and they are capable of loving because God loved them first (1 Jn 4:19). Through the caregiver's love for others, he or she will bring hope to the hopeless. However, this love and hope can never be sourced from within the caregiver's self. God has blessed his people with hope through the cross of Christ. Caregivers need to share this hope through love; however, this sharing, as Poser (1987:22) puts it, will come through 'empty hands'. Everything the Christian is, and all he or she has, or ever does have, was put on the altar of Jesus Christ. Christian caregivers received those gifts they require for the furtherance of God's Kingdom from God himself. Hence, caregivers cannot care unless God cares for them; they cannot give love unless they have received love from God; they cannot bring hope unless God has given them hope.

\section{Hope in the midst of suffering}

Human beings live in three dimensions of time: we have the past tense, a present tense and a future tense. Existence includes accepting the givens imposed by the past, living with the freedoms provided in the present and shaping the possibilities of the future (Stone 2001:261). From Stone, the reader can understand that once care seekers embrace the past and present as reality in their lives, the future will contain many possibilities. Whether these possibilities will be positive or negative depends largely upon the attitude of the care seeker. Paul is of the impression there is one very important condition caregivers and care seekers must adhere to before they can strive towards that to which God has called them: a positive future. 'But one thing I do: Forgetting what is behind and straining towards what is ahead' (Phlp 3:13). Could it be that Paul said that our history is bad; that only negative things live in our past? From the context of this passage, the reader will appreciate that this is not the message Paul is bringing. There are many good things in the 
past, just as there are many bad things. Paul's message urges his reader not to allow the past to hold them back from a bright future. We have discovered that even good things in the past and present have the potential to keep people from reaching towards hope in a bright future.

However, it is most often the negative past stories which keep people from striving towards this future, because, in the midst of these difficult times, people feel separated from God. Being separated from God becomes a real problem, which Yancey (1988:252) challenges as he writes: 'When God seems absent, he may be closest of all. When God seems dead, he may be coming back to life'. From Jesus' experience upon the cross, God understands people's loneliness in their suffering. At Gethsemane and Calvary, God himself was forced to be confronted with separation from God: 'God striving for God' (Martin Luther, cited in Yancey 1988:282). On that difficult day, God had to learn, for himself, what it means to feel God-forsaken. Many people would argue that God does not hide from his people, as a religious bumper sticker on motor vehicle which one of us saw, testifies: 'If you feel far from God, guess who moved?' Yet, the Book of Job teaches us that God can move away. Even though Job had done nothing wrong and even though he cried for help, God still chose to hide from him.

There are also those people who deny these painful circumstances in their lives because they find it so hard to believe, asking themselves how this could really be happening in the full knowledge of God. In their opinion, it must be Satan's doing. Who else could be to blame? Some suffering people believe that if they persevere long enough, the 'enemy' will tire and move on. Sadly, their denial of what God is doing in their lives, separates them from God and his purpose in their lives, leaving them at a hopeless place.

Yet, there is also another option. The care seeker could enter into their suffering and wrestle with God. In the Bible, Jacob's wrestling with God lasted throughout the night, but the sun rose again the next morning and it ended his struggle (Gn 32:28). According to Ross and Ross (2000:15), there is a strong link between hearing and overcoming in biblical culture. Hence, people cannot claim to have heard unless they are willing to overcome. Without wrestling with God in the midst of suffering, people cannot overcome the pain. How then could these people claim to have heard what God was saying through the suffering, because they could not overcome their pain? Jacob wrestled with God and walked away limping; yet, he also overcame. Most often, peoples' wrestling with God will leave them scarred for life. God is deeply interested in bringing new life into people. He wants to heal the world. This healing process, however, will not come without cost (Yancey 1988:198). People's re-creation in God will leave them limping, but, ultimately, it has cost God more: his own Son, because it is through the scars upon God's Son that humans are saved (Is 53:5).
In addition, in the progression of injustice and pain Jesus never became self-focused. In this time of suffering, Jesus intervened, improving life quality for people around him. He did it 'to secure the increase of life and privilege of another' (Dortzbach 2002:25). From this, we see that Jesus' suffering became a redemptive suffering, because he never isolated himself from his people. His suffering actually became the means he used, binding people's wounds in a deeply human manner. His wounds became a source of healing rather than an increase in misery (Dortzbach 2002:109). How could Jesus do this? In our minds, this was only possible because Jesus never lost focus on the fact that his Father is near, even when he cried that dreaded creed, 'my God, my God, why ...' (Mt 27:46). Yet moments later, he committed his Spirit into the hands of the Father who was close enough to receive this from his Son.

\section{Conclusion}

God has called his Church to care for those in need. We care through empty hands, because we have hope through a relationship with God. This hope will come to care seekers in the form of a self-denying Church, reflecting the love that it experienced in Christ. However, hope in Christ, will urge caregivers into action on behalf of those suffering people, because God himself reacted, opposing evil. Hence, real hope cannot be sourced from within the self, but it will come from the God that lives within us: Emmanuel, God with and within us.

\section{Acknowledgements Competing interests}

The authors declare that they have no financial or personal relationship(s) which may have inappropriately influenced them in writing this article.

\section{Authors' contributions}

This article has been adapted from the PhD dissertation of T.H.S. (University of Pretoria) which was completed under the supervision of M.J.M. (University of Pretoria).

\section{References}

Bauckham, R. (ed.), 1999, God will be all in all, T and T Clark, Edinburgh.

Bloch, E., 1986, The principle of hope, TJ Press, London.

Callahan, K., 1983, Twelve keys to an effective Church, Harper and Row, San Francisco, CA.

Conradie, E.M., 2005, 'On human finitude and eternal life', Scriptura - International Journal of Bible Religion and Theology in Southern Africa 88, 30-51.

Crabb, L., 1988, Inside out, Navpress, Colorado Springs, CO.

De Beer, S. (ed.), 2002, Hidden treasure, Pretoria Community Ministries, Pretoria.

Dortzbach, K., 2002, 'Wholeness and healing in community', PhD dissertation, Department of Science of Religion and Missiology, University of Pretoria.

Fitzgerald, R. (ed.), 1979, The sources of hope, Pergamon Press, Sydney.

Harries, R. (ed.), 1986, Reinhold Niebuhr and the issues of our time, A.R. Mowbray, London.

Jackson, W.C., 1985, Spiritual dimensions of pastoral care, Westminster Press, Philadelphia, PA. 
Lester, A.D., 1995, Hope in pastoral care and counselling, Westminster/John Knox Press, Louisville, $\mathrm{KY}$.

Moltmann, J., 1965, Theology of hope, SCM Press, Norwich.

Pannenburg, W., 1975, Faith and reality, Search Press, London.

Patton, J., 1993, Pastoral care in context, Westminster/John Knox Press, Louisville, KY. Poser, K., 1987, Called to be neighbours, WCC Publishers, Geneva.

Roberts, R.H., 1990, Hope and its hieroglyph - A critical decipherment of Ernst Bolch's principle of hope, Scholars Press, Atlanta, GA.
Ross, R. \& Ross, Y., 2000, Go and make disciples, Haifa, Israel.

Schaeffler, R., 1994, Therefore we remember, Liturgical Press, Collegeville, MN.

Stone, H., 2001, 'Hope and possibility: Envisioning the future in pastoral conversation', The Journal of Pastoral Care 55(3), 247-265.

Thatcher, A., 1974, 'Three theologies of the future', Baptist Quarterly 25, 222-253.

Villa-Vicencio, C. (ed.), 1987, Theology and violence - The South African debate, Skotaville Publishers, Johannesburg.

Yancey, P., 1988, Disappointed with God, Zondervan, Grand Rapids, MI. 